\title{
Level of Readiness to Become Entrepreneurs among Lifelong Learning Programmes Participants in Malaysian Community Colleges
}

\author{
Noorazman Abd. Samad ${ }^{*}$, Mohd Shahzuan Ghazalan², Wan Mohd Rashid \\ Wan Ahmad ${ }^{3}$, Affero Ismail ${ }^{4}$, Hairuddin Harun ${ }^{5}$, Mohd Erfy Ismail ${ }^{6}$, Mohd \\ Hasril Amiruddin ${ }^{7}$ \& Nizamuddin Razali ${ }^{8}$ \\ ${ }_{1,2,3,4,5,6,7,8}$ Fakulti Pendidikan Teknikal dan Vokasional, Universiti Tun Hussein Onn Malaysia, 86400 Batu Pahat, Johor, \\ MALAYSIA
}

DOI: https://doi.org/10.30880/jtet.2019.11.01.018

Received 29 $9^{\text {th }}$ August 2018; Accepted 22 ${ }^{\text {nd }}$ October 2018; Available online $31^{\text {st }}$ March 2019

\begin{abstract}
An entrepreneur needs to be physically and mentally prepared, with creative thinking skills, risk taker attitudes, as well as being a wise decision maker. Individuals aiming to be successful entrepreneurs need to have adequate entrepreneurial readiness with respect to knowledge, interests, motivation and abilities. The purpose of the research is to measure the level of readiness towards becoming entrepreneurs among participants of the lifelong learning programme in Malaysian community colleges. This research focuses on four elements of readiness comprising knowledge, interest, motivation and ability which were measured using a self-perception questionnaire. The sample for this research consisted of 236 participants from 305 students in the Lifelong Learning (LL) programme for Pastry making at Malaysian community colleges under the Ministry of Education. Data were analysed using mean and Kruskal Wallis test. The data analyses results show that the level of readiness from the aspect of knowledge $(\mathrm{M}=3.67, \mathrm{SD}=0.58)$ is moderate, interest $(\mathrm{M}=4.13, \mathrm{SD}=0.55)$ is high, motivation $(\mathrm{M}=$ $4.13, \mathrm{SD}=0.55)$ is high and ability $(\mathrm{M}=3.8852, \mathrm{SD}=0.64)$ is moderate. No difference was found on entrepreneurial readiness between participants of different age groups indicating that age may not be a contributing factor towards entrepreneurship among pastry making LL programme participants.
\end{abstract}

Keywords: Keywords: Entrepreneurial readiness; lifelong learning; entrepreneurship; community colleges.

\section{Introduction}

Technical and vocational education and training (TVET) is an educational transformation plan that affects socioeconomic growth and quality of graduates. One of the emphases outlined in the Malaysian TVET report is to empower graduates with entrepreneurial skills to help reduce unemployment. The 2018 Labour Statistics Report (National Statistics Department 2018) states that unemployment rate has increased of $3.3 \%$ as of April 2018 compared to 10 years ago with 510,000 are unemployed, based on 15,313,100 current workers (JPN, 2018). Generally, unemployment issues are caused by job choices, lack of experience, mismatch qualifications, lack of preparation, limited soft skills, competing foreign workers and immigrants and the poor attitude of local workers. However, from the aspect of individual internal factor, lack of readiness in graduates involving knowledge, interest, motivation and ability in the field of work to be carried out are the main reasons for unemployment. In entrepreneurship in particular, individual's internal factor is critical, as committing oneself to pursuing entrepreneurship challenges requires a high level of readiness (Ghazalan et al, 2018). Ghazalan et al (2018) suggest that the knowledge, interest, motivation and readiness increase a student's tendency to become successful entrepreneurs in the future. Hence, one of the main causes of the 
inability of an individual to become an entrepreneur is due to lack of readiness in the aspects of knowledge, interest, motivation and ability.

Therefore, The Ministry of Higher Education (MOHE) has entrusted the community colleges to empower the local community with entrepreneurial skills via the establishment of a Lifelong Learning programme to train participants to become entrepreneurs which will indirectly reduce unemployment. However, there are Lifelong Learning programme participants who are unable to become entrepreneurs after completing their courses at community colleges. This could be due to their lack of readiness to become entrepreneurs which is unknown and never assessed. Therefore, this research aims to measure the level of readiness of participants in lifelong learning programmes towards pursuing entrepreneurship endeavours. The findings will help community colleges determine the readiness level of their graduates and to gauge the adequacy of their curriculum in preparing graduates to become entrepreneurs. The findings can then be used to improve existing curriculum to support better development of future entrepreneurs.

In addition to the curriculum, age has been identified in some studies as a strong predisposing factor in a person's inclination to become entrepreneur and to be successful in entrepreneurship endeavours (Meika \& Lukman, 2017; Muin, Abdullah \& Bahari, 2016). According to Muin, Abdullah and Bahari (2016), age is an important factor in the success of a business and starting early in adolescence is beneficial as at adolescence, individuals are energetic with efficient thinking to overcome business challenges. However, some researchers disagree that age is a factor affecting the tendency to become entrepreneurs (Ghazalan, 2015). Due to conflicting findings, an investigation should be undertaken to identify whether the age factor affects the readiness of lifelong learners to become entrepreneurs.

\section{Entrepreneurial Development Model}

This section describes two models of entrepreneur development process that is Basic Model of Entrepreneurial Process and Model of Entrepreneurial Development Process.

\subsection{Basic Model of Entrepreneurial Process}

Figure 1 shows the basic model in the entrepreneurial process developed by Barringer and Ireland (2006). Based on this model, two-way arrows between the decision to become entrepreneurs and develop successful business ideas show that the opportunity to develop an idea causes one to decide to become an entrepreneur. The basic model of entrepreneurial processes consists of three main factors that encourage an individual to decide in becoming an entrepreneur. The factors are; to become an employer, to pursue ideas and to achieve financial independence. Four factors that have been listed namely are, making a decision to become an entrepreneur, developing a successful business idea, turning to the ideas into entrepreneurial firms and manage and develop entrepreneurship firm.

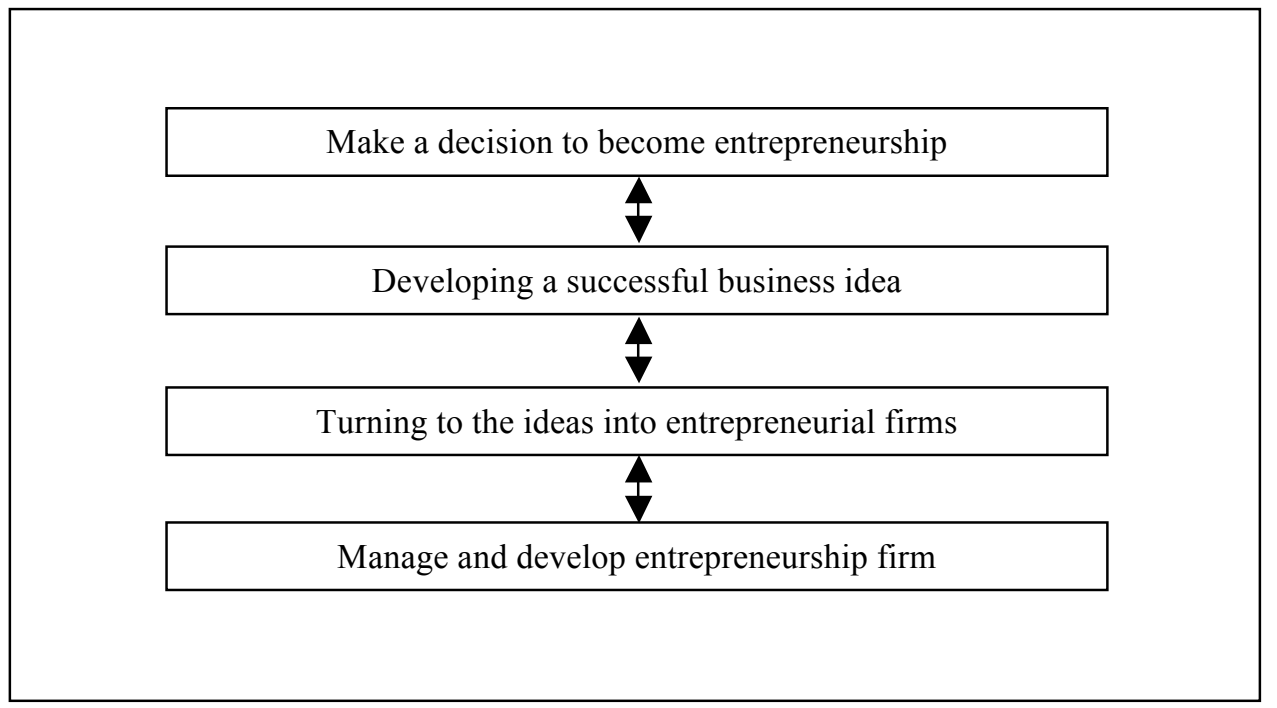

Fig. 1 - Basic model of entrepreneurial process

(Source: Barringer \& Ireland, 2006)

\subsection{Model of Entrepreneurial Development Process}

The model of the process of entrepreneurship developed by Ahmad, Jabeen and Khan (2014) is indicated below. The process shows that at three stages to become entrepreneur. It is based on the individual's decision to choose whether to become an entrepreneur or to gain experience by working in advance as indicated in Figure 2 . These three phases influence the four factors that have been selected, namely the entrepreneurial background, attitudes, motivation and skills. Entrepreneurs can be influenced either at the level of graduates. 


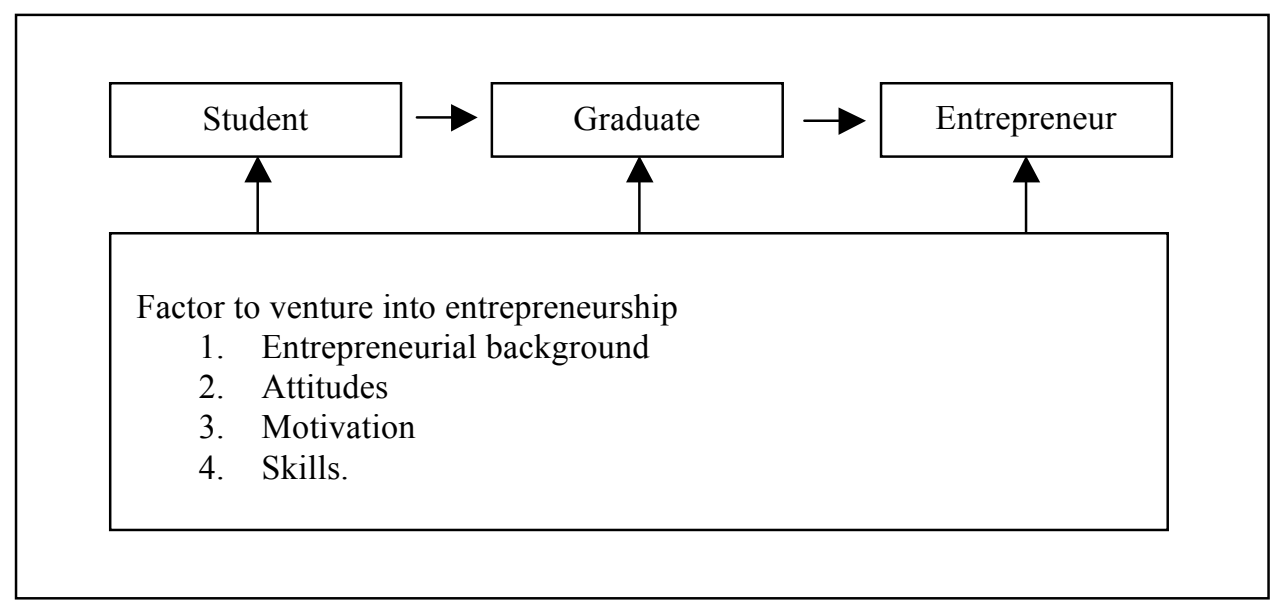

Fig. 2 - Model of entrepreneurial development process

(Source: Ahmad, Jabeen \& Khan, 2014)

\section{Methodology}

This research uses a survey design using quantitative approaches that examine the level of readiness of participants at the LL programme. The analysis using descriptive and inferential analysis where the data analysis is done in the form of mean and Kruskal Wallis test analysis to find the difference. The questionnaire was used as a research instrument.

\subsection{Population}

The total population is 305 participants of the Lifelong Learning (LL) programme in Pastry field. The population of this research is consisting of LL pastry participants at Ledang Community College (LCC), Batu Pahat Community College (BPCC) and Tanjung Piai Community College (TPCC). The population consists of prospective LL Programme members at Ledang Community College (LCC), Batu Pahat Community College (BPCC) and Tanjung Piai Community College (TPCC), who graduated (Short-Term Course, STC) from Community Colleges in 2015 based on participation statistics in 2014.

\subsection{Research Sample}

Based on the sampling method, 236 respondents were selected using a simple random sampling method (Krejcie and Morgan, 1970). Sample was randomly chosen, as it is easy to provide equal opportunities to individuals in the population to be involved as a sample of this research in representing the population being studied (Green and Thorogood, 2018). According to Semykina and Wooldridge (2018), by using a simple random sampling method, each element within the population has an equal opportunity to be selected into a sample. Table 1 shows the sample targets based on the sampled population (Krejcie and Morgan, 1970).

Table 1 - Population targets and samples based on 2014 statistics for April and May 2015

\begin{tabular}{clcc}
\hline No. & Institutions & Population & Sample \\
\hline 1. & Batu Pahat Community College (BPCC) & 110 & 80 \\
2. & Tanjung Piai Community College (TPCC) & 95 & 76 \\
3. & Ledang Community College (LCC) & 100 & 80 \\
\hline & Total & 305 & 236 \\
\hline
\end{tabular}

(Source: Statistics on short term course implementation at Community College, 2014)

\subsection{Instrument}

The researchers have adapted questionnaires from Halid, (2012) and Nasharudin, and Harun, (2010). This questionnaire consists of five constructs covering 60 questionnaire items. Respondents were asked to respond to Questionnaire items using the 5-point Likert scale starting with (1) = Strongly Disagree, (2) = Disagree, (3) = Less agree, (4) = Agree and (5) = Strongly Agree. In this research, opinions of three experts were sought with respect to their language and entrepreneurial expertise to ensure reliability and validity of the questionnaire. The pilot test was conducted on LL programme participants from the Segamat Community College (SSC) with 30 questionnaires distributed to Short Course participants in Pastry making programme with 100 percent returned rate. Reliability analysis (Table 2) shows 
that Cronbach's Alpha value for all individual constructs exceed 0.8 while the overall Alpha is above 0.93 indicating a highly reliable instrument.

Table 2 - Cronbach's Alpha coefficients for individual construct and overall instrument

\begin{tabular}{lcc}
\hline \multicolumn{1}{c}{ Contract } & $\begin{array}{c}\text { Cronbach's } \\
\text { Alpha value }(\boldsymbol{\alpha})\end{array}$ & $\begin{array}{c}\text { Number of } \\
\text { Items }\end{array}$ \\
\hline $\begin{array}{l}\text { Section A: Perception of LL programme participants on the readiness } \\
\text { of knowledge in entrepreneurship. }\end{array}$ & 0.937 & 19 \\
$\begin{array}{l}\text { Section B: Perception of LL programme participants on the Interest of } \\
\text { entrepreneurship. }\end{array}$ & 0.846 & 12 \\
$\begin{array}{l}\text { Section C: Perception of LL programme participants to the motivation } \\
\text { of entrepreneurship. }\end{array}$ & 0.808 & 7 \\
$\begin{array}{l}\text { Section D: Perception of LL programme participants on the ability of } \\
\text { entrepreneurship. }\end{array}$ & 0.802 & 12 \\
$\begin{array}{l}\text { Section E: Perception of LL programme participants to tendency in } \\
\text { entrepreneurship. }\end{array}$ & 0.923 & 60 \\
\hline Total & 0.930 & 6 \\
\hline
\end{tabular}

\section{Data Analysis}

\subsection{Readiness Level of LL Programme Participants}

Table 3 shows the overall result of the level of entrepreneurial readiness among LL participants based on their perceptions. The results indicate that LL programme participants have a moderate level of entrepreneurship knowledge (Mean=3.67), high interest on entrepreneurship (Mean= 4.13), high entrepreneurial motivation $($ Mean=4.13) and moderate entrepreneurship ability (Mean=3.88).

Table 3 - Readiness level from the aspect of knowledge, interest, motivation and ability

\begin{tabular}{clcc}
\hline No & \multicolumn{1}{c}{ Construct } & Mean & Level \\
\hline 1. & Knowledge & 3.67 & Moderate \\
2. & Interest & 4.13 & High \\
3. & Motivation & 4.14 & High \\
4. & Ability & 3.88 & Moderate \\
\hline
\end{tabular}

\subsection{Entrepreneurial Readiness Level Based on Age of LL Programme Participants}

Table 7 is the result of the levels of readiness to become an entrepreneur according to age of LL programme participants. By observing the mean rank score for each age group of the LL programme participants, there is a difference in the level of readiness between LL participants.

To select a data analysis method some procedures should be done between identifying the data distribution. The suitability of data for the upcoming analysis is tested using several methods namely data filtering procedures (Outliner Data), skewness and kurtosis normality test and Kolmogorov-Smirnov normality test.

\subsubsection{Data Filtering Procedures (Outliner Data)}

In this analysis, some data were deleted because the data is not relevant and out of the data environment. However, after the screening process, the data was still not normal. Refer to Table 4 and Figure 3 below.

Table 4 - Outliner data

\begin{tabular}{cccccc}
\hline Construct & $\begin{array}{c}\text { Number Of } \\
\text { Respondent }\end{array}$ & Minimum & $\begin{array}{c}\text { Maximu } \\
\text { m }\end{array}$ & Mean & Std. Deviation \\
\hline Readiness & 236 & 2.15 & 5.00 & 3.9855 & 0.47945 \\
Tendency & 236 & 1.00 & 5.00 & 4.2758 & 0.64409 \\
\hline
\end{tabular}




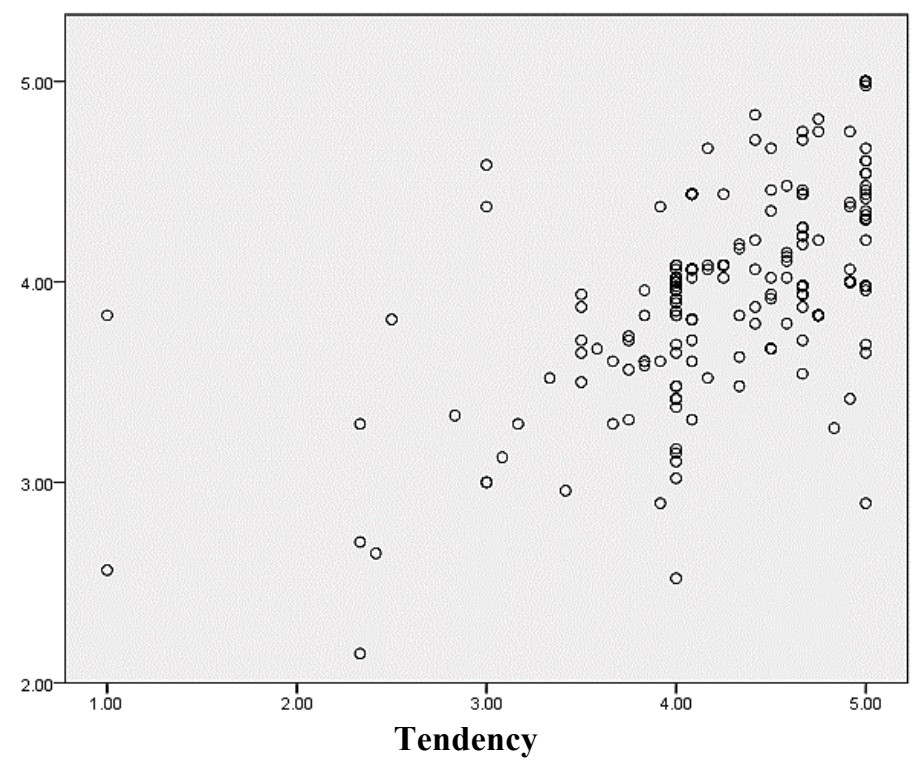

Fig. 3 - Outliner data

\subsubsection{Normality Test}

The results from the normality test indicated that the Skewness and Kurtosis values of the tendencies are -1.674 and 5.388, which is more than \pm 1 indicating that data are not normally distributed as the values exceed the specified distance of \pm 1 . Results from the normality test resulted Skewness and Kurtosis values of readiness level are -0.481 and 1.351 , which is more than \pm 1 indicating that the data are not normally distributed as the values exceed the specified distance of \pm 1

Table 5 - Result for Skewness and Kurtosis Normality Test

\begin{tabular}{|c|c|c|}
\hline Construct & Test & Statistic \\
\hline \multirow[t]{2}{*}{ Readiness } & Skewness & -0.481 \\
\hline & Kurtosis & 1.351 \\
\hline \multirow[t]{2}{*}{ Tendencies } & Skewness & -1.674 \\
\hline & Kurtosis & 5.388 \\
\hline
\end{tabular}

\subsubsection{Kolmogorov-Smirnov For Normality Test}

The Kolmogorov's normality test was significant with $\mathrm{p}=.000$ indicating that a non-parametric statistical test should be used for testing differences between groups (Razali \& Wah, 2011). According to Lilliefors (1967), a parametric test is used only if the $\mathrm{p}$ value is greater than 0.05 . Therefore, the researchers decided to use Kruskal Wallis chi-square test.

Table 6 - Result for Kolmogorov-Smirnov Normality Test

\begin{tabular}{lccc}
\hline & Construct & Kolmogorov-Smirnov $^{\text {a }}$ & \\
\hline & Statistic & df & p-value \\
Readiness & 0.118 & 236 & 0.000 \\
Tendencies & 0.182 & 236 & 0.000 \\
\hline
\end{tabular}

\subsubsection{Kruskal Wallis Chi-Square Test}

The findings of the Kruskal Wallis chi-square test were 2.968 with a significant level $(p=0.397)$. Therefore, the result shows that the value of 0.397 is more than 0.05 . Test results demonstrate that there is no statistically significant difference in the levels of readiness towards entrepreneurs between LL programme participants of different age groups.

Table 7 - Result for Kruskal Wallis test

\begin{tabular}{cc}
\hline Statistic & Readiness \\
\hline Chi-Square & 2.968 \\
Df & 3 \\
$p$-value & 0.397 \\
\hline
\end{tabular}




\section{Discussion}

\subsection{Readiness Level of LL Programmes Participants to Venture into Entrepreneurship}

Entrepreneurship consists of knowledge among LL participants programme in community colleges who have been exposed to entrepreneurship. In line with the JPKK entrepreneurial development agenda model, the direction of the community college entrepreneurship development in 2020 is at the high level (Jabatan Pengajian Kolej Komuniti, 2018). This statement is further reinforced by the presence of the Community College Entrepreneurship Development Planning Plan which aims to increase the number of entrepreneurs according to the targets set from 2010 - 2015 (JPKK, 2018).

Hence, the findings of the researcher are at moderate that consist of interest and motivation due to the government's policies to introduce entrepreneurship education to students aged 15 years old. This statement is supported by Newbery, Moizer and Haddoud (2018) who indicate that the level of learning and education will influence entrepreneurship development stages. This is in line with the statement by Nabi et al. (2017) which state that entrepreneurial education is a lifelong learning process ranging from primary to tertiary education. In addition, this statement is supported by Ghazalan (2015) that being exposed into the preparation of entrepreneurial is increasingly inclined to entrepreneurship.

Nevertheless, the researcher is of the opinion that the level of knowledge on readiness has yet to reach the highestlevel due to lack of formal and informal education in the field of entrepreneurship. The findings are in line with the research conducted by Hannon (2018) that final year students in a technical college university in Malaysia lack knowledge in the field of entrepreneurship. This is supported by Amiruddin, Samad and Othman (2015) and Hariri (2018) who emphasized the capabilities required in individuals to become entrepreneurs is knowledge.

The result report shows that the Community College participants have tendency to become an entrepreneur. However, readiness especially in knowledge level related to entrepreneurship needs to be improved. Therefore, relevant agencies such as community colleges should play a role in planning and continuing efforts to help participants become successful entrepreneurs in the future.

\subsection{Relationship Between Readiness Level of LL Programme Participants and Age}

For the aspect to determine the difference between the level of readiness and the age of Lifelong Learning (LL) programme participants in entrepreneurship, the findings show that there is "no difference between the level of readiness and the age of LL programme participants in entrepreneurship. Hence, the hypothesis concludes, "there is no significant difference between the level of readiness to entrepreneurs with the age of participants of the community college Lifelong Learning programme in the tendency of entrepreneurship". This reflects that the age factor does not determine the readiness of LL programme participants. Researchers think this decision is due to the development of entrepreneurship knowledge that has been learned from the school level so participants have been exposed to early entrepreneurship. This resulted in the findings of the LL programme in the field of entrepreneurship. This decision coincides with the study conducted by Ghazalan (2015) which states that age does not affect the tendency to become entrepreneurs.

\section{Conclusion}

In conclusion, the overall LL programme participants have a high readiness level to venture into entrepreneurial fields that is, they have a tendency to become entrepreneurs. However, the level of readiness related to knowledge of the entrepreneurial field needs to be strengthened. Therefore, more concerted efforts should be undertaken to ensure a more effective implementation of the above-mentioned programme. Among the proposals to be taken into account is that the level of knowledge of LL programme participants on the entrepreneurial field is still at moderate level. Therefore, involved parties such as instructors need to increase their knowledge in advance about the field of entrepreneurship. In addition, the instructors must also work and improve their teaching delivery techniques to be more effective, compact, attractive, concise and of adequate quality. This is to encourage interest and thus motivate the LL programme participants to engage in entrepreneurship. In this regard, community colleges need to increase entrepreneurship innovation to advanced, small and medium entrepreneurs. Subsequently, to further enhance the readiness of participants in community college on this entrepreneurial field, seminars, and programmes on entrepreneurship can also be conducted at community colleges. Community colleges may devise and organize any activities and programmes in collaboration with government and private bodies directly involved with the entrepreneurial field. This will help participants to be more vulnerable to entrepreneurial knowledge. Finally, the role of print and electronic media is also important to provide the latest information on the world of entrepreneurship. Campaigns can be held continuously in the mass media so that those interested in this field can explore and make plans in the field of entrepreneurship. Based on the proposals, the researchers are confident that the application of LL programme participants' readiness will be 
enhanced if the stakeholders in this research have implemented the proposed proposals. The finding from this research may also help community colleges in drawing up a suitable curriculum that will address the gap in existing entrepreneurial curriculum. With appropriate curriculum, the readiness of LL programme participants to venture into entrepreneurship can be enhanced.

\section{Acknowledgement}

This paper was partly sponsored by the grant PPG U16 UTHM. Appreciation to Faculty of Technical and Vocational Education and University Tun Hussein Onn Malaysia (UTHM) and to MyBRAIN15 (MyPHD) for their researcher to finish this research.

\section{References}

Ahmad, S. Z., Jabeen, F., \& Khan, M. (2014). Entrepreneur's choice in business venture: Motivations for choosing home-stay accommodation businesses in Peninsular Malaysia. International Journal of Hospitality Management, 36 , $31-40$.

Amiruddin, M.H., Samad, N. A., \& Othman, N. (2015). An Investigation Effects of Mastery Learning Strategy on Entrepreneurship Knowledge Acquisition among Aboriginal Students. Procedia-Social and Behavioral Sciences, 204, 183-190.

Barringer \& Ireland (2006). Entrepreneurship: Successfully Launching New Ventures. Prentice Hall, New Jersey, pp $18-19$

Ghazalan, M. S., Samad, N. A., Ab Halim, F., Hamidon, N. I., \& Hariri, T. I. A. A. (2018). Level Readiness Participant of Lifelong Learning (LLL) Programme Venture Into Entrepreneurship. In MATEC Web of Conferences (Vol. 150, p. 05029). EDP Sciences.

Green, J., \& Thorogood, N. (2018). Qualitative methods for health research. Sage.

Ghazalan, M. S. (2015). Tahap kesediaan peserta programme Pembelajaran Sepanjang Hayat (PSH) dalam kecenderungan menceburi keusahawanan di kolej komuniti Negeri Johor. Doctoral dissertation, Universiti Tun Hussein Onn Malaysia.

Hariri,T.I., Mohamad, M.M, Roddin, R. Asri,M. Ghazalan,.M.S (2018). Keupayaan Komuniti Keusahawanan Dalam Kalangan Suku Kaum Orang Kuala Di Rengit, Johor. Ejournal 8 (2018), 1 - 7.

Hannon, P. D. (2018). On becoming and being an entrepreneurship educator: a personal reflection. Entrepreneurship \& Regional Development, 1-24.

Halid (2012). Kesediaan Pelajar Politeknik Kejurteraan Elektrik Dalam Menceburi Bidang Keusahawanan. Jurnal Pendidikan Malaysia, 87 - 97.

Jabatan Pengajian Kolej Komuniti (JPKK) 2018. Kolej Komuniti Ledang. Dicapai pada Julai 02, 2018 dari http://www.jpkk.gov.my

Kementerian Pendidikan Malaysia (KPM) (2016). Pelan Tindakan Keusahawanan 2016-2020 (Pendidikan Tinggi). Putrajaya, Malaysia: Kementerian Pendidikan Malaysia. Dicapai pada Julai 31, 2018

Krejcie, R. V., \& Morgan, D. W. (1970). Determining sample size for research activities. Educational and psychological measurement, 30(3), 607-610.

Lilliefors (1967). On the Kolmogorov-Smirnov Test for Normality with Mean and Variance Unknown. Journal of the American Statistical Association, 62 (318), 399-402.

Meika, S. A., \& Lukman Fauroni, M. A. (2017). Pengaruh Persepsi Harga, Inovasi Dan Kualitas Produk Terhadap Keberlangsungan Usahawan Home Industry Rotan Di Desa Trangsan Kecamatan Gatak Kabupaten Sukoharjo Tahun 2016. Doctoral Dissertation, Iain Surakarta.

Muin, M. A. A., Abdullah, S., \& Bahari, A. (2016). Keusahawanan Sosial Islam: Faktor--faktor Penglibatan Usahawan Sosial Berjaya Muslim. Journal home page, 1(1).

Newbery, R., Lean, J., Moizer, J., \& Haddoud, M. (2018). Entrepreneurial identity formation during the initial entrepreneurial experience: The influence of simulation feedback and existing identity. Journal of Business Research, 85, 51-59. 
Nabi, G., Liñán, F., Fayolle, A., Krueger, N., \& Walmsley, A. (2017). The impact of entrepreneurship education in higher education: A systematic review and research agenda. Academy of Management Learning \& Education, 16(2), 277-299.

Nasharudin, N., \& Harun, H. (2010). Aspirasi Kerjaya Keusahawanan dalam Kalangan Pelajar Institusi Pengajian Tinggi Awam. Malaysian Journal of Education, 35(1).

Razali \& Wah (2011). Power comparisons of Shapiro-Wilk, Kolmogorov-Smirnov, Lilliefors and Anderson-Darling tests. Journal of Statistical Modelling and Analytics, 2 (1), 21-33.

Semykina, A., \& Wooldridge, J. M. (2018). Binary response panel data models with sample selection and self-selection. Journal of Applied Econometrics, 33(2), 179-197. 